\title{
WHAT DO BUSINESS ASSOCIATIONS DO?
}

\author{
GÁBOR TAMÁS MOLNÁR
}

\begin{abstract}
This article provides a review of the literature on business associations (BAs) in line with the following questions: (1) What are the economic roles of BAs, (2) How are BAs institutionalized, and (3) What drives BAs to engage in socially beneficial or harmful activities? Challenging the popular distinction between beneficial, market-supporting and harmful, rent-seeking (lobbying) goals of $B A s$, we demonstrate that there are three major economic roles of BAs, all of which can involve activities linked to the private order and the public order, and all of which can be socially beneficial or harmful. We also challenge the proposition that institutional strength is needed for BAs to fulfil beneficial economic roles, highlighting that BAs have three main institutional functions, and the level of institutionalization of each of the functions can be different in relation to their beneficial economic roles. We suggest that whether BAs tend toward engage in in socially beneficial or harmful activities depends on their private-order and publicorder institutional limitations.
\end{abstract}

KEYWORDS: business associations, institutional order, collective action, trade associations, industry associations

\section{INTRODUCTION}

What do business associations do? For a long time, economists viewed BAs as "interest groups" engaged in rent-seeking by influencing public decisions (Ekelund - Tollison, 2001). As for their functioning, the crucial question

\footnotetext{
${ }^{1}$ Gábor Tamás Molnár is PhD candidate at the Doctoral School of Political Science, Corvinus University of Budapest. email: gabortamas.molnar@uni-corvinus.hu. Author recieved support from project EFOP-3.6.1-16-2016-00013 ('Institutional developments for intelligent specialization at the Székesfehérvár Campus of Corvinus University of Budapest').
} 
appeared to be whether they could develop appropriate internal incentives for overcoming free-riding and promoting collective action. As Olson famously argued (Olson, 1971), for larger groups this typically meant the introduction of "selective incentives" for participation by a "political entrepreneur." In the 1990 s, scholars in the "new institutional" tradition started to challenge this received view (Greif, 2008), leading to the explicit attack mounted in a pair of articles by Doner and Schneider (Doner - Schneider, 2000; Schneider - Doner, 2000). The former authors argued and illustrated using several examples that business associations pursue many other goals besides "rent-seeking."

What do BAs actually do? Empirical studies based on the subjective evaluations of stakeholders have demonstrated the importance of several distinct activities of BAs in different contexts, but have not led to clear conclusions (Battisti Perry, 2015; Bennett, 1998; Bennett - Ramsden, 2007; McCormick et al., 2008; Rochlitz, 2016; Yakovlev et al., 2014). We suggest that the contradictory nature of such empirical results is explained by business associations fulfilling various economic roles that are relevant to a different extent in different contexts. Furthermore, the same activity may fulfil different economic roles at the same time, such as is the case with providing information to policy makers to obtain benefits for an industry. There can also be significant differences between the economic roles observed by those participating in collective action, and the actual effects of collective action (Ville, 2007).

The standard approach of most studies has been to look at the presence of certain activities or the presence of certain outcomes related to these activities. Our goal is not to argue for any specific theory of BA functionality. Instead, we employ a model approach, in which we suggest starting with an analysis of the institution and its main goals, and then structuring the manifold activities that are identifiable along these lines. This article provides a review of the literature on BAs within a new conceptual framework. Its goals are twofold: (1) to highlight the common features of these diverse institutions and what we know about them, and (2) to challenge two widespread propositions about their economic roles.

Our starting point is that the main research question should be divided into three further sub-questions:

1. What are the economic roles of BAs?

2. How are BAs institutionalized in order to fulfil their economic roles?

3. What drives BAs to engage in socially beneficial or harmful activities?

Following these lines of questioning, we provide some structure for our knowledge about the subject, point out the gaps therein, and identify potentially fruitful directions for future research, while challenging two widespread propositions about the economic roles of BAs. 
In section two, we provide a conceptualization of BAs as an umbrella term for private, formalized, non-commercial organizations that are intended to further the business interests of their members. We highlight the position of BAs as planned, private-order institutions positioned in-between spontaneous and public-order institutions.

In section three we deal with our first question by providing a typology of the many economic roles of BAs based on how they contribute to fulfilling their basic goals. Following a review of the literature in this area, we seek to challenge the widespread distinction between the beneficial-, market-supporting- and the harmful-, rent-seeking/lobbying goals of BAs by demonstrating that (1) all of the studied economic roles of BAs can involve activities linked to the privateorder and the public-order, and that (2) all of the studied economic roles can be linked to both socially beneficial and harmful activities.

Section four reviews our knowledge in relation to the second question concerning institutionalization. We suggest that BAs have three basic institutional functions in relation to solving collective action problems: (1) information-sharing, (2) rule-articulation, and (3) incentivizing compliance. These institutional functions can be institutionalized at different levels, constituting four distinct ideal types of institutional forms of BAs: (1) intermediary, (2) associational governance, (3) self-regulation, and (4) co-regulation. Reviewing the literature from this perspective, we challenge Doner - Schneider's (2000) claim that a business association needs a certain level of institutional strength to be able to fulfil beneficial, "market-supporting" economic roles by demonstrating that beneficial contributions are possible at each of the different levels of institutionalization in relation to each of the economic roles of BAs.

Section five structures our rather limited knowledge about the topic of the third question. We propose that whether BAs institutionalize socially beneficial economic roles depends on the institutional incentives by which they are affected. Five main drivers of the beneficial roles of BAs emerge from the scarce evidence. Private-order constraints on BAs include (1) market pressure on the membership of BAs, (2) internal governance solutions to principal-agent problems, and (3) the competition between BAs and other similar institutions. Public-order constraints of BAs depend on (4) political accountability, and (5) the monitoring capabilities of public-order institutions.

Section six concludes and points out what we consider the most important avenues for further research on BAs. 


\section{THE NATURE OF BUSINESS ASSOCIATIONS}

\section{The main features of $B A s$}

There are many related concepts used in political economy for the institutionalized collective action of businesspeople: business-, professional-, sectoral-, and industrial associations, all sorts of entrepreneurial and rotary clubs, as well as chambers of commerce belong to this group. We adopt Prüfer's (2016) synthesis of earlier definitions, whereby business associations are [considered] private, formalized, non-commercial organizations, intended to further the business interests of their members. BAs are private institutions, based at least partially on the voluntary cooperation of their members. They include semi-voluntary or mandatory membership organizations if these also institutionalize voluntary cooperation, and thus are not entirely public-order, governmental institutions. BAs are formalized institutions, which means that they have their own rules about membership and decision-making, and are longterm structures in contrast to ad-hoc coalitions of business collective action (Doner - Schneider, 2000, p. 280).

Since BAs are intended to further the business interests of certain groups of businesses, they are distinctive in relation to the business communities that exist behind these organized interests (Saitgalina et al., 2016). Business communities can be defined by their common knowledge base, common interests or common values, and goals. The former can result from (1) being engaged in similar occupations or in similar markets and industries, (2) being embedded in similar institutional orders due to geographical proximity, or by (3) belonging to similar communities outside of business, such as religious or political groups. The three dimensions can intersect in various ways, defining various forms of associations. Associations can be linked to specific occupations (professional associations), industries and interests (industry, trade and cluster associations), or the broad occupational group of entrepreneurship (entrepreneurial associations and business clubs). They might involve underlying value-based communities, such as Christian business clubs or Lions clubs. They can be local clubs, regional or national associations, or even international or global associational confederations. In our review, we use the term business association for all the above institutions insofar as they fit our criteria. 


\section{BAs as planned private-order institutions}

Business associations are planned, private-order institutions positioned somewhere between spontaneous and planned public-order institutions (Greif, 2008). This means that BAs build upon the spontaneous private order of markets and communities, but are also able to overcome some of the limitations of the former due to their planned nature. They also differ from public-order institutions in that they are private, voluntary institutions. This position means that BAs are bridging organizations that connect informal community structures to the formal public-order. Their economic roles are determined by the limitations of each alternative, but they can also build upon the resources of their informal base or their public-order relations. The distinguishing feature of BAs among planned, private institutions is that they feature a separate, non-commercial form of central organization and multilateral relations, instead of bilateral relations structured by a profit-oriented central actor (Lindberg et al., 1991).

\section{THE ECONOMIC ROLES OF BUSINESS ASSOCIATIONS}

\section{Business associations as rent-seeking}

A widespread approach in the literature distinguishes between the beneficial, market-supporting and the harmful, rent-seeking role of BAs, the latter which is often associated with lobbying (Battisti - Perry, 2015; Duvanova, 2013; Marques, 2017; Sukiassyan - Nugent, 2011; Ville, 2007). We suggest that it is perhaps better to approach the issue starting with the understanding of BAs as institutions intended to further the goals of a business community. This means that BAs are inherently "rent-seeking" institutions in the broad sense that their basic goal is to increase the economic rent of a community of firms.

In the broader economic sense, rents are returns in excess of the opportunity costs of resources spent on an activity (Tollison, 1982). Rent-seeking as the pursuit of economic rent thus understood is the essential driving force behind all economic activity. In this sense, rent-seeking is not necessarily a negative term, as rents can be obtained by value-creating activities such as developing a new product or reducing production costs. Such innovative rent-seeking activities lead to increased market power and higher returns or lower opportunity costs, increasing the innovator's economic rent.

Rent-seeking in its public-choice sense generally refers to non-value-creating, redistributive ways of obtaining economic rent. Classic examples include 
increasing market power through reducing competition through entry barriers, and seeking transfers from other groups by influencing public decisions (Tollison, 2012). These activities redistribute rents from other individuals instead of creating new value, and are therefore harmful to society in that they lead to wasted economic effort. We can associate the socially beneficial economic roles of BAs with value-creating, rent-seeking activities, while their socially harmful activities are those aimed at redistributive rent-seeking.

By reviewing the economic roles that business associations fulfil from this perspective, we seek to illustrate that it is possible for both "market-supporting" and "lobbying" types of activities to represent beneficial, value-creating and harmful, redistributive rent-seeking. In order to do this, we demonstrate-based on previous studies - that (1) all of the studied economic roles of BAs can involve activities linked to the private-order and the public-order, and that (2) all of their economic roles can contribute to both value-creating and redistributive rent-seeking.

There are three main types of economic role, defined by the three ways through which BAs can contribute to value-creating rent-seeking. The first type may be called the vertical economic role, because it is mainly concerned with transactions along the value chain. This economic role enables more valuecreating transactions by reducing transaction costs and protecting the rents obtained from those transactions. The second type may be called a horizontal economic role, because it concerns the cooperation that occurs within business communities aimed at securing public goods for themselves. These public goods contribute to value-creating rent-seeking by lowering costs and enabling innovative economic activities. The third type is that of the external economic role, as it is concerned with the relations of business communities to other social groups. By contributing to the resolution of social conflict, it enables the community to protect its economic rent. We do not consider redistributive rentseeking to be a separate economic role of BAs, but instead propose that any of the economic roles of the latter can involve redistributive elements, if the institutional context allows this.

\section{Vertical economic role: enabling more value-creating transactions}

BA activities in the first group are defined by their economic role in improving the transactional order of the business community. These concern vertical relationships along value chains that may be found inside or outside the community. While the other economic roles of BAs also contribute to better 
functioning markets, in the former cases collective action directly enables value-creating transactional solutions.

\section{Protecting property rights}

BAs have an economic role as private, planned, coercion-constraining institutions (Greif, 2008). By sanctioning breaches of property rights, such as public expropriation or violent takeover of assets, these activities increase the incentive of private actors to invest in economic activities, thus enabling more complex forms of cooperation (Duvanova, 2007, 2013; Hedberg, 2011; Pyle, 2011; Rochlitz, 2016; Yakovlev et al., 2014). Association activities related to this economic role include spreading information about violations of rights, coordinating sanctions against violators through suspending transactions (Kazun, 2015), and pressuring the government to guarantee property rights (Mikamo, 2013).

\section{Reducing transaction costs}

The other basic transaction-enabling role of BAs involves reducing transaction costs. Business associations may help lower transaction costs in a variety of ways (Recanatini - Ryterman, 2001), resulting in more value-creating transactions. These can include lowering search costs by providing information about potential partners, lowering bargaining costs by coordinating common contractual frameworks, or lowering enforcement costs by improving existing contract enforcement mechanisms or institutionalizing new ones.

By providing platforms for information-sharing and the development of informal ties, associations reduce the cost associated with finding business partners, as well as the cost of contracting (De Clercq et al., 2010). Associations contribute to increasing credible commitment in contractual relationships by both improving the spread of information about rule-breakers and helping coordinate sanctions against them (McMillan - Woodruff, 2000). These institutions can enable decentralized, reputation-based contract enforcement (Prüfer, 2016; Pyle, 2005, 2006b), as well as reduce the costs associated with formal contract enforcement through offering arbitration services. Sanctioning opportunism can be expected to increase the credibility of both members' promises and promises made to members (Johnson et al., 2002). BAs can also institutionalize professional and ethical regulations for dealing with reputation commons (Barnett, 2006). Similarly to the case of credible commitments, business 
associations contribute to the latter through facilitating information sharing, which enables third-party or community enforcement, or by institutionalizing this enforcement themselves (Lenox - Nash, 2003).

\section{Horizontal economic roles: providing public goods}

BAs can facilitate the provision of public goods, enabling more value-creating transactions through reducing costs and encouraging innovative business activity.

\section{Maintaining the knowledge base of the community}

Associations can play various economic roles in relation to the provision of knowledge required for a business community. Firms can organize and co-fund training and certification activities through business associations (Maennig et al., 2015; McCormick et al., 2008). This helps to overcome the free-rider problem inherent in the spread of on-the-job training and non-specific, transferable knowledge, as firms can funnel-in employees from other companies who have invested in knowledge, leading to low-effort equilibrium. An important aspect of business associations' capacity for spurring innovation is their ability to foster information sharing, whether through channeling scientific results into the professional community (Luna - Tirado, 2008) or through developing networks (Schwartz - Bar-El, 2015). Due to knowledge spillover effects, participants in these networks have positive external effects on each other (De La Maza-YAramburu et al., 2012).

The successful participation of professionals in the exploratory processes of innovation and governance requires more than gathering and applying information. Business associations can create the institutional settings for the development of professional identities, shared intellectual foundations, and professional solutions, all of which are required for the successful adaptation of an industry to changing conditions (Greenwood et al., 2002; Nordqvist et al., 2010). Mike (2017) applies Michael Polányi’s (1951) concept of intellectual order to conceptualize the underlying institutionalized communities behind an industry or profession. An intellectual order entails more than information sharing, as it institutionalizes a shared search for truth in the form of professional solutions, new ideas, and the ethos of professionalism, as well as mediating between industry and related intellectual fields of science and technology. 


\section{Joint provision of infrastructure}

By collectively developing and maintaining infrastructure, BAs can take advantage of external economies of scale without having to give up their autonomy (Kingsbury - Hayter, 2006). This allows them to reduce their costs, leading to higher economic rent. Examples include jointly organized, capitalintensive R\&D activities (Lamberg et al., 2017), as well as maintaining shared sales infrastructure (Hashino - Kurosawa, 2013; McNamara, 1993).

\section{External economic roles: Coordinating solutions to social conflicts}

In such cases, collective action goes beyond the direct goals of the business community and involves coordinating relations with other groups in order to protect rent, or to obtain external resources. Social conflicts arise from differences between the economic rationality of the business community and the goals of other social groups. Conflicts can be resolved by engaging with the other stakeholders directly or through government policy.

\section{Resolving social conflicts}

BAs can be used for resolving conflicts that arise from the external effects of the business community's activities on other social groups. Marques (2017) provides a recent review of the social-responsibility-related activities of BAs. These might allow for structured engagement and bargaining with stakeholders (Dickson - Arcodia, 2010), defining and enforcing professional standards for dealing with external effects (Font et al., 2019; King - Lenox, 2000), or generating self-regulation that helps maintain a shared social reputation (King et al., 2002; Tucker, 2008).

\section{Coordinating involvement in (development-, economic-, social-, etc.) policies}

Business associations can be involved in the formulation and implementation of various government policies. Areas such as development policy (Hashino Kurosawa, 2013) and economic stabilization policies (Schneider - Doner, 2000) may benefit from the involvement of private institutions. Associations can also aggregate the opinions of their members and transmit them to policymakers. This contributes to the public good of having more informed, higher quality 
policies (Chappin et al., 2008). Business associations can help with overcoming horizontal coordination problems associated with economic development, such as the acceptance of technological and quality standards (Schneider Doner, 2000). These coordination activities do not necessarily replace market competition, but are able to elevate it to new levels (Berk - Schneiberg, 2005).

\section{Redistributive rent-seeking}

There are four ways for BAs to engage in redistributive rent-seeking, none of which necessarily involve lobbying or even engaging with the public-order, as they can also rely on the private-order.

BAs can be platforms for (1) collusive practices, whereby firms reduce competition through agreements (McMillan - Woodruff, 2000, pp. 3, 38). Reduced competition leads to redistribution from potential entrants and consumers. Collusive practices can be organized under the pretense of any joint activities, but they are most relevant for economic roles that involve horizontal coordination, whether for providing public goods or for resolving external conflict. Collusion can also result from the coordination of contractual rules, which belongs to the transaction cost-reducing role. These arrangements can only be stable if entry barriers are present or entrants are incentivized to join such agreements. (2) Entry barriers are mainly related to ethical and professional self-regulation, which are elements of vertical and external economic roles.

Both collusion and self-regulation require selective benefits to become stabilized, while these benefits themselves can lead to (3) exclusive institutional orders (Johansson - Elg, 2002). When property rights or contracts are only selectively enforced, or access to public goods and external mediation is selectively provided, this can lead to entry barriers for agents external to BAs, therefore lessening competition. The intellectual orders of business communities can also be barriers to change if they are closed in nature (Mike, 2017), thereby protecting the entrenched interests of incumbents, instead of supporting more efficient solutions. Selective access to resources can be based on any of the listed economic roles, if they are allowed to become exclusive in their institutionalization.

The textbook case of redistribution involves (4) coercion in relation to obtaining resources from other groups, which in contemporary polities is exercised through the state. In the absence of an effective public order, mafialike BAs can extract resources directly from other groups through private-order coercion. Redistribution through coercion is mostly related to the external economic roles of BAs, but it can also involve activities linked to protecting property rights. 


\section{HOW ARE BAs INSTITUTIONALIZED?}

Doner - Schneider (2000) propose that there is a relationship between the beneficial contributions of BAs and their institutional strength, claiming that a certain level of institutionalization is needed for a business association to be able to fulfil beneficial, "market-supporting" economic roles. While it is true that associations at different levels of institutionalization contribute in different ways, the relationship does not seem to be that straightforward. It is perhaps better to approach the question from the perspective of the institutional functions underlying the economic roles of BAs. We distinguish three institutional functions of BAs, and propose that each of them can be institutionalized at different levels, constituting four typical institutional forms. From a review of the literature regarding this approach, we seek to demonstrate that beneficial contributions related to each of the economic roles of BAs are possible at each of the different levels of institutionalization.

\section{How can BAs contribute?}

How can BAs contribute to solving the various collective-action problems in which they are involved? Collective-action problems generally require institutional solutions, and different levels of the former require different levels of institutional arrangements to support stable cooperative solutions. Pure coordination problems only require the institutionalization of common knowledge that is created among actors. Coordination problems with a conflictual element require some form of institutionalized rules of compensation. Rules in this context can be defined as "shared understandings by participants about enforced prescriptions concerning what actions or outcomes are required, prohibited, or permitted" (Ostrom, 2005, p. 18). Prisoner's-dilemma type problems require the institutionalization of rules and sanctions in order to overcome free-riding concerns.

BAs can contribute to each of these institutional solutions by supporting any of the three main institutional functions that are involved: information-sharing for the creation of common knowledge, rule-articulation for defining compensatory institutions and creating focal points which increase commitment to solutions, and institutionalizing sanctions for incentivizing compliance with rules. 


\section{Information-sharing}

BAs can institutionalize information-sharing by (1) providing a forum for their community, (2) sharing information themselves as central intermediaries, (3) structuring and formalizing information-sharing, and (4) incentivizing structured information sharing by community members. These activities allow community members to become aware of collective action problems, the actors involved in collective problems, and the goals of stakeholders who are involved. This institutional function does not change the set of stable solutions that are available, but reduces the costs associated with coordinating solutions and incentivizing compliance through other institutional mechanisms through equalizing the information available to each actor.

\section{Rule-articulation}

BAs can contribute to rule-articulation at various levels. They can (1) provide a common platform for members to articulate rules, (2) institutionalize rulearticulation to provide common processes, or (3) provide formalized ways of defining rules. These functions allow community members to better coordinate solutions to collective problems without changing the set of stable solutions itself, and by institutionalizing focal points for harmonizing expectations about what others are going to do.

\section{Incentivizing compliance}

To incentivize compliance with rules, BAs can either (1) improve the functioning of sanctions provided by other institutions, or (2) institutionalize their own associational sanctions. By incentivizing compliance, BAs can modify the set of stable solutions that is available for managing collective action problems.

\section{Levels of BA institutionalization}

Based on the analysis of institutional functions in the previous section, we can derive four distinct institutional forms of BA. These theorized forms are ideal types. Although subsequent levels build on each other, the order reflects the level of institutionalized collective action, not a development path. Several 
different forms might co-exist within the same community. The following subsections describe each ideal type in terms of the institutionalization of each of the three institutional functions, while Table 1 provides an overview of the four institutional forms.

\section{Intermediary association}

The first level of institutionalization corresponds roughly to what Galambos (1966) in his theory of BA institutionalization called a "dinner-club association." An information intermediary BA provides a platform for sharing information that "greases the gears" of other institutional mechanisms. It provides no formal rules or incentives at the BA level, instead relying on those provided by other institutions. It is useful for harmonizing beliefs and expectations within and around the business community that foster spontaneous contract enforcement mechanisms based on ethics, social norms, and reputation, or for facilitating information to and from public-order institutions in order to improve their functioning. Information intermediaries do not create stable solutions to collective action problems themselves, but might reduce the transaction costs of coming up with and maintaining solutions.

\section{Associational governance}

In addition to sharing information, associational governance means that common rules are articulated at the BA level. Associational governance is exercised through a process of structured bargaining (Ville, 2007), which means that it is not self-regulation yet, as at this level the BA itself does not institutionalize sanctions related to compliance. It rather contributes to harmonizing expectations about what actions are considered right within the community, and providing focal points for solving collective action problems, without changing the incentive structure of a situation itself. Its economic role as a rule-setting platform provides a BA with a natural central position as an information-sharing institution as well.

\section{Self-regulation}

The term "self-regulation" is often used to mean solutions at any of the first three levels of institutionalization. For our purposes, we define a self- 
regulatory association as one in which, in addition to information-sharing and rule-articulation, incentivizing compliance with the rules of the community is also institutionalized at the associational level. This requires the BA not only to articulate but also to formalize common rules and create sanctions at the BA level that are backed by their own selective incentives. These incentives are tied either directly to rule-compliance or to membership itself, with membership being tied to rule-compliance. This allows the self-regulatory BA to change the payoff structure of collective action problems, changing the set of feasible stable solutions at the community level. Sanctioning at the associational level also tends to require BAs to formalize some information sharing in order to fulfil their monitoring function, while it also provides them with the tools to incentivize compliance with the procedures of information sharing.

Self-regulation does not necessarily imply a lack of public-order regulatory mechanisms, but merely that privately designed regulation mechanisms operate without direct reliance on the former. Nor does self-regulation mean a lack of reliance on informal mechanisms. The dividing line is the existence of institutionalized sanctioning mechanisms at the collective level.

\section{Co-regulation}

The final institutional form is co-regulation, which represents an alternative solution to the problem of institutionalizing selective incentives. A co-regulatory association receives the backing of the public-order in the form of the legal sanctions or resources on which its sanctions are based (Muraközy - Valentiny, 2015). These often include mandatory membership or participation, or granting official legal status to rules and decisions of the association. These additional resources might provide co-regulatory BAs with even greater capacity to restructure problems of collective action. Co-regulation is also expected to institutionalize information-sharing and rule-articulation, even if it tends to include public-order rules and information sources. Co-regulation often blurs the line between voluntary and mandatory association, as related activities are not necessarily all backed by public legal sanctions. 
Table 1 Level of institutionalization of the three main institutional functions for the four typical forms of institutionalization

\begin{tabular}{|c|c|c|c|}
\hline $\begin{array}{c}\text { Level of collective } \\
\text { action }\end{array}$ & Information-sharing & Rule-articulation & $\begin{array}{l}\text { Incentivizing } \\
\text { compliance }\end{array}$ \\
\hline $\begin{array}{l}\text { Intermediary } \\
\text { association }\end{array}$ & $\begin{array}{l}\text { Platform + (possibly } \\
\text { central) information } \\
\text { intermediary }\end{array}$ & $\begin{array}{l}\text { Provided by other } \\
\text { institutions }\end{array}$ & $\begin{array}{l}\text { Provided by other } \\
\text { institutions }\end{array}$ \\
\hline $\begin{array}{l}\text { Associational } \\
\text { governance }\end{array}$ & $\begin{array}{c}\text { Platform }+ \text { Central } \\
\text { information } \\
\text { intermediary }\end{array}$ & $\begin{array}{l}\text { Articulated (and } \\
\text { formalized) at the } \\
\text { association level }\end{array}$ & $\begin{array}{l}\text { Provided by other } \\
\text { institutions }\end{array}$ \\
\hline Self-regulation & $\begin{array}{l}\text { Platform + Central } \\
\text { information } \\
\text { intermediary } \\
\text { + Formalized, } \\
\text { possibly compulsory } \\
\text { information-sharing }\end{array}$ & $\begin{array}{l}\text { Articulated and } \\
\text { formalized at the } \\
\text { association level }\end{array}$ & $\begin{array}{c}\text { Associational } \\
\text { sanctions based on } \\
\text { membership benefits } \\
\text { and services }\end{array}$ \\
\hline Co-regulation & $\begin{array}{l}\text { Platform + Central } \\
\text { information } \\
\text { intermediary } \\
\text { + Formalized, } \\
\text { possibly compulsory } \\
\text { information-sharing }\end{array}$ & $\begin{array}{c}\text { Articulated and } \\
\text { formalized at the } \\
\text { association level }+ \\
\text { some have official } \\
\text { public status }\end{array}$ & $\begin{array}{c}\text { Associational } \\
\text { sanctions based on } \\
\text { membership benefits } \\
\text { and services }+ \text { formal } \\
\text { legal sanctions } \\
\text { or state-provided } \\
\text { incentives }\end{array}$ \\
\hline
\end{tabular}

\section{Levels of institutionalization and the economic roles of $B A s$}

Doner - Schneider (2000) propose that a certain level of institutionalization is needed for a business association to be able to fulfil market-supporting economic roles. We suggest that each of the four levels of institutionalization is relevant for each of the proposed economic roles, as BAs with different levels of institutional strength can contribute in different ways. In the following sections we provide an overview of the economic roles which BAs at different levels of institutionalization are able to fulfil, attempting to highlight that (1) all institutional levels, even including simple information intermediaries, can be beneficial, and that (2) higher levels of institutionalization can enable harmful forms of rent-seeking, not only beneficial coordination.

If intermediary BAs can rely on spontaneous or public-order sanctions, they are able to coordinate various forms of collective action. They can enable valuecreating transactions by spreading information about business partners and regulations (Betton et al., 2018; Cai - Szeidl, 2018; Johnson et al., 2002; Leonidou - Katsikeas, 1997; Pyle, 2005, 2006b; Recanatini - Ryterman, 2001), and about breaches of property rights (Pyle, 2011; Rochlitz, 2016). They can improve 
knowledge-sharing (Costa et al., 2017; Kirby, 1988; Luna - Tirado, 2008; Pyle, 2006a; Qiao et al., 2014) and reduce the transaction costs of coordinating shared infrastructural projects (McNamara, 1993). They can also reduce the cost of engagement with stakeholders in relation to externalities (Dickson - Arcodia, 2010) and on developing and implementing public policies (Schneider, 2010; Stolz - Schrammel, 2014).

BAs at the level of associational governance can articulate common goals and rules, which enable them to orient collective action in various cases if they can connect these to other institutional incentives. They can coordinate contracts and knowledge-sharing to reduce transaction costs (Herrigel, 1993; Lane - Bachmann, 1997; Rademakers, 2000), to facilitate joint investment in public goods (Berk - Schneiberg, 2005) and innovation (Faulconbridge, 2007; McCormick et al., 2008; Nordqvist et al., 2010; Perez-Aleman, 2003). They can enable community reputational mechanisms in contract enforcement (Masten - Prüfer, 2014; Prüfer, 2016), the protection of property rights (Dixit, 2015; Hedberg, 2011; Nugent - Sukiassyan, 2009), and in dealing with social conflicts (Font et al., 2019; King - Lenox, 2000). They can also articulate communitylevel interests to improve policymaking.

The presence of formal sanctioning and monitoring capacities enable selfregulatory $B A s$ to institutionalize solutions to the problems of free-riding and preference heterogeneity. They can help enforce the self-regulation of ethical and professional standards for contract enforcement (Bernstein, 1992, 2001; Dentoni et al., 2012; Gehrig - Jost, 1995; Gunningham - Rees, 1997; McMillan - Woodruff, 2000; Ville, 2007), the protection of property rights (Larrain Prüfer, 2015) and resolving external conflicts (Christiansen - Kroezen, 2016; King - Berchicci, 2007; Tucker, 2008). They are able to institutionalize the community provision of public goods by incentivizing contributions (Kingsbury - Hayter, 2006; Lamberg et al., 2017), and to formalize knowledge networks for innovation (Greenwood et al., 2002; Kahl, 2018; Schwartz - Bar-El, 2015). They are also able to enforce community-level deals with external stakeholders and policymakers.

Public-order incentives allow co-regulatory BAs to tackle most conflictual prisoner's-dilemma types of collective action problems. They can institutionalize even stronger sanctions to support quality and ethical regulations, contributing to contract enforcement (Coleman, 1989; Muraközy - Valentiny, 2015), property rights protection (Mikamo, 2013; Yakovlev et al., 2014) and the management of social conflicts (Bartle - Vass, 2007; Héritier - Eckert, 2009; Marques, 2017; Rees, 1997). They can combine public and private resources to provide public goods related to infrastructure and knowledge provision (Athreye-Chaturvedi, 2007; Hashino - Kurosawa, 2013). They can also enable the implementation and 
enforcement of even contentious policies to improve outcomes (Schneider, 2010; Schneider - Doner, 2000).

This review, along with Section 3.5, demonstrates that stronger institutionalization does not necessarily lead to more beneficial (or less harmful) activities, while BAs with simpler institutional forms are also able to fulfil beneficial roles, depending on the collective problems and contexts at hand.

\section{WHAT DRIVES BAS TO ENGAGE IN SOCIALLY BENEFICIAL OR HARMFUL ACTIVITIES?}

We have suggested that the beneficial or harmful nature of the activities of BAs in relation to economic development is not explained by the presence of specific, non-market-oriented activities, nor by the institutional strength of BAs. What then, does explain the beneficial or harmful orientation of BA activity? We agree with the proposition of Reveley and Ville (2010) that whether the institutional capacity of BAs is used for beneficial or for harmful purposes mainly depends on the institutional constraints of the latter and the BAs' own institutional governance solutions. It is possible to classify institutional constraints by their sources. Here, the starting point that BAs are positioned between private-order and public-order is once again helpful, as the former constraints stem from the private-order of the community underlying the BA, or the public-order in which a BA is embedded. We provide an overview of the scarce literature on the institutionalization of BAs that goes beyond the issue of selective incentives, highlighting what we consider the four most important questions and the gaps in our knowledge about them.

\section{Community (membership) constraints on rent-seeking}

As a BA is constituted by its membership, the goals of the underlying business community are expected to influence its goals. The first question related to this is (1) "when is the underlying business community incentivized to pursue value-creating transactions?" The members of a BA are expected to opt for redistributive rent-seeking instead of value-creating transactions if doing so increases their economic rent. Competitive pressures can create oversight and encourage productivity (Doner - Schneider, 2000), as less productive rentseekers might fall behind in market competition.

It is not enough for members to be motivated to pursue value-creating activities; the issue of control is also involved. The second question is thus 
(2) "when is the business community able to incentivize the BA to pursue its activities in line with the community's goals?" Without some control, BA officials can pursue their own goals (Moore - Hamalai, 1993), or become coopted by powerful subgroups. The first way for members to control BAs is hierarchically, which depends on the success of the internal governance solutions of the BA at resolving principal-agent problems. Several elements of institutional strength identified by Doner and Schneider (2000) are related to this issue. To avoid being controlled by narrow interest groups, BAs need to be able to mediate between members with different interests, for which they need transparency and institutionalized forms of internal discourse. Studies about the failure of self-regulation also call our attention to how business associations need to find institutional balance in representing different member groups in order to avoid their capture by the most influential group for their own rent-seeking purposes (Aldrich, 2018; Barnett, 2013; Yue et al., 2013).

The second way for members to control BAs is indirectly through interassociation competition. Ville (2007) demonstrates that competition between BAs encourages productive roles instead of redistributive, rent-seeking efforts. Hock and Gomtsian (2018) propose that a lack of competition was a major factor in the development of harmful rent-seeking practices in the case of FIFA. Control by other associations can also emerge through the counter-organization of affected stakeholder groups (Reveley - Ville, 2010; Schneiberg, 1999).

\section{Public-order constraints on rent-seeking}

The other source of institutional constraints on harmful rent-seeking is the public-order (Doner - Schneider, 2000; Reveley - Ville, 2010). This constraint depends on the willingness and the capacity of the public-order to steer BAs toward productive activities. Therefore, the third question is (3) "when are the agents of the public order incentivized to be responsive to the interests of the broader community?" This is a question of political accountability, which is outside of the scope of this review. We have some evidence in the Russian case that political competition and political accountability incentivize policy-makers to pay more attention to more encompassing interests (Govorun et al., 2016).

The final question is (4) "when are agents of the public order able to control the activity of the BA?" There is a fundamental problem of information asymmetry here, as a business community inevitably knows more about its workings than any regulatory agency. There is a further issue of regulatory capture here: as government agents develop closer relationships and more capacity to understand and monitor business communities, they become increasingly 
likely to internalize their goals instead of enforcing the interests of the broader political community (Dal Bó, 2006; Levine - Forrence, 1990). If the interests of the business community and the polity do not align, multiple layers of principalagent problems can result, whereby the relative successes of private and publicorder actors determine the activities of BAs (Mattli - Büthe, 2005). We suggest that further research is needed about all four issues.

\section{CONCLUSIONS AND THE WAY FORWARD}

In this article we suggest that, in order to understand what business associations really do, we need to approach them not in terms of observable activities, but rather in terms of their underlying institutional rationality. We formulated three questions stemming from our main research question. (1) What are the economic roles of Bas, (2) How are BAs institutionalized in order to fulfil their economic roles, and (3) What drives BAs to engaging in socially beneficial or harmful activities?

We claim that BAs are "rent-seeking" institutions broadly understood, as their main goal is to increase the economic rent of a community of businesses. There are three main economic roles through which they can enable valuecreating rent-seeking: (1) vertical economic roles, which enable more valuecreating transactions along the value chain, (2) horizontal economic roles, which enable the provision of public goods which can contribute to economic rents, and (3) external economic roles, which allow for coordinating the goals of business communities with those of other social groups in order to protect economic rent. We challenge the widespread approach in the literature which distinguishes between the beneficial, market-supporting, and the harmful, rentseeking / lobbying roles of BAs by demonstrating that (1) all of the proposed economic roles of BAs can involve activities linked to the private-order and the public-order, and that (2) all of the economic roles can contribute to both valuecreating and redistributive rent-seeking.

Regarding the institutionalization of BAs, we suggest that they have three basic institutional functions in relation to solving collective action problems: (1) information-sharing, (2) rule-articulation, and (3) incentivizing compliance. These institutional functions can be institutionalized at different levels, with four distinct ideal types of BA institutionalization emerging: (1) intermediary BAs, (2) associational governance, (3) self-regulation, and (4) co-regulation. We challenge the proposition by Doner - Schneider (2000) that a certain level of institutional strength is needed for a business association to be able to fulfil 
beneficial, "market-supporting" economic roles, by highlighting that beneficial contributions from each of the economic roles of BAs are possible at each of the different levels of institutionalization.

After proposing that the socially beneficial role of BAs is not explained by the presence of specific, non-market-oriented activities, nor by the institutional strength of BAs, we give an overview of our limited knowledge concerning what drives BAs to engage in socially beneficial or harmful activities. We suggest that the institutional incentives created by the private-order and publicorder context explain the orientation of BAs. We hypothesize five main drivers of productive orientation: (1) market pressures on the membership of BAs, (2) internal governance solutions to principal-agent problems, (3) the competition between BAs and other similar institutions, (4) political accountability, and (5) the monitoring capabilities of public-order institutions.

We cannot claim that the typologies of our literature review are exhaustive or sufficiently detailed for in-depth empirical analysis. The main contribution of this study is to highlight that economic roles, institutional functions, and drivers of social productivity are distinct, and that instead of conflating them in our theories, we should approach them at the level of underlying institutional logics in order to link them.

How does distinguishing between the three questions contribute to addressing the original puzzle about the nature of BAs? Distinguishing roles allows us to go beyond observed activities and to analyze the functional requirements for each role in its specific institutional context. Distinguishing functions allows us to analyze the institutionalization of each function and then link them to the requirements of each role. The issue of social benefit also needs to be tackled separately for each economic role by linking them to the general institutional constraints of BA activities.

BAs are positioned between the private-order institutions of business communities and public-order institutions of governance, and can complement or compete with either. Private-order institutions such as firms, alliances, and contractual solutions determine the kinds of collective problems facing BAs, as well as their resources for dealing with them. We can also expect different BA features to be relevant in neo-corporatist versus pluralist systems, and at the supranational, national, and local level, mainly due to the resources and constraints provided by the relevant public-order institutions. This means that empirical analyses of functionality and institutionalization must deal with both the external institutional context and the private-order contexts of business communities. Any comparative or natural experiment-based analysis of BAs needs to focus on either specific roles (such as contract enforcement), specific business communities (industries or professions), or specific systems of 
governance (policy areas or polities) to deal with the problems of embeddedness and multifunctionality.

For a comprehensive understanding of BAs, we need to go beyond specific functions and theorize about the relations between the different functions: do their underlying institutional logics complement each other, or do they result in organizational tensions and trade-offs? Answering these questions can shed light on the institutional dynamics, development paths, and institutional equilibria for BAs. There has unfortunately been little progress on this topic since Schmitter - Streeck's (1999) pioneering work on the logics of association. The institutionalization typology of this paper presents ideal types for structuring our review and challenging some of the claims in the literature, but we invite scholars to come up with more nuanced theories about the levels of BA institutionalization and the factors underlying its processes. Doing this will require more in-depth, interdisciplinary studies about the institutionalization of business communities and their associational systems that draw on economics, business history, and political science, following the steps of Galambos (1966), Greif (2006), and Reveley - Ville (2010).

\section{REFERENCES}

Aldrich, H. E. (2018), "Trade Associations Matter as Units of Selection, as Actors Within Comparative and Historical Institutional Frameworks, and as Potential Impediments to Societal Wide Collective Action". Journal of Management Inquiry, Vol. 27. No 1, pp. 21-25. https://doi.org/10.1177/1056492616688857

Athreye, S. - Chaturvedi, S. (2007), "Industry Associations and Technologybased Growth in India". The European Journal of Development Research, Vol. 19. No 1, pp. 156-173. https://doi.org/10.1080/09578810601144426

Barnett, M. L. (2006), "Finding a Working Balance Between Competitive and Communal Strategies". Journal of Management Studies, Vol. 43. No 8, pp. 1753-1773. https://doi.org/10.1111/j.1467-6486.2006.00661.x

Barnett, M. L. (2013), "One Voice, But Whose Voice? Exploring What Drives Trade Association Activity". Business \& Society, Vol. 52. No 2, pp. 213-244. https://doi.org/10.1177/0007650309350211

Bartle, I. - Vass, P. (2007), "Self-Regulation Within the Regulatory State: Towards a New Regulatory Paradigm?" Public Administration, Vol. 85. No 4, pp. 885-905. https://doi.org/10.1111/j.1467-9299.2007.00684.x

Battisti, M. - Perry, M. (2015), "Small enterprise affiliations to business associations and the collective action problem revisited". Small Business 
Economics, Vol. 44. No 3, pp. 559-576. https://doi.org/10.1007/s11187-0149607-z

Bennett, R. J. (1998), "Business associations and their potential contribution to the competitiveness of SMEs". Entrepreneurship \& Regional Development, Vol. 10. No 3, pp. 243-260. https://doi. org $/ 10.1080 / 08985629800000014$

Bennett, R. J. - Ramsden, M. (2007), "The Contribution of Business Associations to SMEs: Strategy, Bundling or Reassurance?" International Small Business Journal: Researching Entrepreneurship, Vol. 25. No 1, pp. 49-76. https://doi. org/10.1177/0266242607071781

Berk, G. - Schneiberg, M. (2005), "Varieties in Capitalism, Varieties of Association: Collaborative Learning in American Industry, 1900 to 1925". Politics \& Society, Vol. 33., No 1, pp. 46-87. https://doi. org/10.1177/0032329204272390

Bernstein, L. (1992), "Opting out of the Legal System: Extralegal Contractual Relations in the Diamond Industry". The Journal of Legal Studies, Vol. 21. No 1, pp. 115-157. https://doi.org/10.1086/467902

Bernstein, L. (2001), "Private Commercial Law in the Cotton Industry: Creating Cooperation Through Rules, Norms, and Institutions". Michigan Law Review, Vol 99., 1724. https://doi.org/10.2307/1290478

Betton, M. E. - Branston, J. R. - Tomlinson, P. R. (2018), "Managerial Hubris, Trade Associations and Regulatory Knowledge in Micro-Firms: Regulatory Knowledge in Micro-Firms", British Journal of Management. https://doi. org/10.1111/1467-8551.12314

Cai, J., - Szeidl, A. (2018), "Interfirm Relationships and Business Performance", The Quarterly Journal of Economics, Vol. 133., No 3, pp. 1229-1282. https:// doi.org/10.1093/qje/qjx049

Chappin, M. M. H. - Hekkert, M. P. - Meeus, M. T. H. - Vermeulen, W. J. V. (2008), "The intermediary role of an industry association in policy-making processes: The case of the Dutch paper and board industry". Journal of Cleaner Production, Vol. 16., No 14, pp. 1462-1473. https://oi.org/10.1016/j. jclepro.2007.08.004

Christiansen, L. H., - Kroezen, J. J. (2016), "Institutional Maintenance through Business Collective Action: The Alcohol Industry's Engagement with the Issue of Alcohol-Related Harm" In J. Gehman, M. Lounsbury, - R. Greenwood (Eds.), Research in the Sociology of Organizations (Vol. 48, pp. 101-143). Emerald Group Publishing Limited. https://doi.org/10.1108/S0733558X201600048B006

Coleman, W. D. (1989), "Self-regulation in the Canadian securities industry: A study of the Investment Dealers Association of Canada" Canadian Public 
Administration/Administration Publique Du Canada, Vol. 32. No 4, pp. $503-$ 523. https://doi.org/10.1111/j.1754-7121.1989.tb01372.x

Costa, E. - Lucas Soares, A., - Pinho de Sousa, J. (2017), "Institutional networks for supporting the internationalisation of SMEs: The case of industrial business associations", Journal of Business \& Industrial Marketing, Vol. 32., No 8, pp. 1182-1202. https://doi.org/10.1108/JBIM-03-2017-0067

Dal Bó, E. (2006), "Regulatory Capture: A Review" Oxford Review of Economic Policy, Vol. 22. No 2, 203-225. https://doi.org/10.1093/oxrep/grj013

De Clercq, D. - Danis, W. M., - Dakhli, M. (2010), "The moderating effect of institutional context on the relationship between associational activity and new business activity in emerging economies", International Business Review, Vol. 19. No 1, pp. 85-101. https://doi.org/10.1016/j.ibusrev.2009.09.002

De La Maza-Y-Aramburu, X. - Vendrell-Herrero, F., - Wilson, J. R. (2012), "Where is the value of cluster associations for SMEs?" Intangible Capital, Vol. 8., No 2, https://doi.org/10.3926/ic.346

Dentoni, D. - Menozzi, D., - Capelli, M. G. (2012), "Group heterogeneity and cooperation on the geographical indication regulation: The case of the "Prosciutto di Parma" Consortium", Food Policy, Vol. 37., No 3, pp. 207-216. https://doi.org/10.1016/j.foodpol.2012.02.003

Dickson, C. - Arcodia, C. (2010), "Promoting sustainable event practice: The role of professional associations" International Journal of Hospitality Management, Vol. 29. No 2, pp. 236-244. https://doi.org/10.1016/j.ijhm.2009.10.013

Dixit, A. K. (2015), "How Business Community Institutions Can Help Fight Corruption", The World Bank Economic Review, Vol. 29. Supplement 1, S25S47. https://doi.org/10.1093/wber/lhv016

Doner, R. F., - Schneider, B. R. (2000), "Business Associations and Economic Development: Why Some Associations Contribute More Than Others", Business and Politics, Vol. 2., No 3, 261-288. https://doi.org/10.2202/14693569.1011

Duvanova, D. (2007), "Bureaucratic Corruption and Collective Action: Business Associations in the Postcommunist Transition", Comparative Politics, Vol. 39. No 4, pp. 441-461. https://doi.org/10.2307/20434054

Duvanova, D. (2013), Building Business in Post-Communist Russia, Eastern Europe, and Eurasia: Collective Goods, Selective Incentives, and Predatory States. Cambridge University Press.

Ekelund, R., - Tollison, R. (2001), The Interest-group Theory of Government. The Elgar Companion to Public Choice. WF Shugart II and L. Razzolini. Edward Elgar.

Faulconbridge, J. R. (2007), "Exploring the Role of Professional Associations in Collective Learning in London and New York's Advertising and Law 
Professional-Service-Firm Clusters", Environment and Planning A: Economy and Space, Vol. 39., No 4, pp. 965-984. https://doi.org/10.1068/a38190

Font, X., - Bonilla-Priego, M. J., - Kantenbacher, J. (2019), "Trade associations as corporate social responsibility actors: An institutional theory analysis of animal welfare in tourism", Journal of Sustainable Tourism, Vol. 27. No 1, pp. 118-138. https://doi.org/10.1080/09669582.2018.1538231

Galambos, L. (1966), Competition \& cooperation: The emergence of a national trade association. Johns Hopkins Press.

Gehrig, T., - Jost, P.-J. (1995), "Quacks, lemons, and self regulation: A welfare analysis", Journal of Regulatory Economics, Vol. 7., No 3, pp. 309-325. https:// doi.org/10.1007/BF01067100

Govorun, A., -Marques, I., - Pyle, W. (2016), "The political roots of intermediated lobbying: Evidence from Russian enterprises and business associations" Business and Politics, Vol. 18., No 4, pp. 395-433. https://doi. org/10.1515/bap-2015-0032

Greenwood, R. - Suddaby, R., - Hinings, C. R. (2002), "Theorizing Change: The Role of Professional Associations in the Transformation of Institutionalized Fields". Academy of Management Journal, Vol. 45., No 1, pp. 58-80. https:// doi.org/10.5465/3069285

Greif, A. (2006), Institutions and the Path to the Modern Economy: Lessons from Medieval Trade. Cambridge University Press. https://doi.org/10.1017/ CBO9780511791307

Greif, A. (2008), "Commitment, Coercion and Markets: The Nature and Dynamics of Institutions Supporting Exchange" In C. Ménard - M. M. Shirley (Eds.), Handbook of New Institutional Economics (pp. 727-786). Springer Berlin Heidelberg. https://doi.org/10.1007/978-3-540-69305-5_29

Gunningham, N., - Rees, J. (1997), "Industry Self-Regulation: An Institutional Perspective" Law \& Policy, Vol. 19., No 4,363-414. https://doi.org/10.1111/14679930.t01-1-00033

Hashino, T., - Kurosawa, T. (2013), "Beyond Marshallian Agglomeration Economies: The Roles of Trade Associations in Meiji Japan" The Business History Review, Vol. 87., No 3, pp. 489-513. https://doi.org/10.1017/ s0007680513000731

Hedberg, M. (2011), Voice, Influence or Security?: The Motives for Membership in Post-Communist Business Associations (SSRN Scholarly Paper ID 1899703). Social Science Research Network. https://papers.ssrn. com/abstract $=1899703$

Héritier, A., - Eckert, S. (2009), "Self-Regulation by Associations: Collective Action Problems in European Environmental Regulation" Business and Politics, Vol. 11., No 1, pp. 1-22. https://doi.org/10.2202/1469-3569.1250 
Herrigel, G. (1993), "Large firms, small firms, and the governance of flexible specialization: The case of Baden Württemberg and socialized risk", In B. M. Kogut (Ed.), Country competitiveness: Technology and the organizing of work (pp. 15-35). Oxford University Press.

Hock, B., - Gomtsian, S. (2018), "Private order building: The state in the role of the civil society and the case of FIFA", The International Sports Law Journal, Vol. 17., No 3-4, pp. 186-204. https://doi.org/10.1007/s40318-0180123-1

Johansson, U., - Elg, U. (2002), "Relationships as entry barriers: A network perspective", Scandinavian Journal of Management, Vol. 18., No 3, pp. 393419. https://doi.org/10.1016/S0956-5221(01)00014-8

Johnson, S. - McMillan, J., - Woodruff, C. (2002), "Courts and Relational Contracts", Journal of Law, Economics, \& Organization, Vol. 18., No 1, pp. 221-277. https://doi.org/10.1093/jleo/18.1.221

Kahl, S. J. (2018), "The Role of Trade Associations in Market Discourse and Cognition", Journal of Management Inquiry, Vol. 27., No 1, pp. 13-15. https:// doi.org/10.1177/1056492616688855

Kazun, A. (2015), "Violent Corporate Raiding in Russia: Preconditions and Protective Factors", Demokratizatsiya, Vol. 23., No 4, pp. 459-484.

King, A. A., - Berchicci, L. (2007), "Postcards from the Edge: A Review of the Business and Environment Literature" (ERS-2007-085-ORG; Research in Management, p. 66). Erasmus Research Institute of Management.

King, A. A., - Lenox, M. J. (2000), "Industry Self-Regulation without Sanctions: The Chemical Industry's Responsible Care Program", The Academy of Management Journal, Vol. 43. No 4, pp. 698-716. https://doi. org $/ 10.2307 / 1556362$

King, A. A. - Lenox, M. J., - Barnett, M. L. (2002), "Strategic responses to the reputation commons problem", In Organizations, policy and the natural environment: Institutional and strategic perspectives (pp. 393-406). Stanford University Press.

Kingsbury, A.,- Hayter, R. (2006), "Business associations and local development: The Okanagan wine industry's response to NAFTA", Geoforum, Vol. 37., No 4, pp. 596-609. https://doi.org/10.1016/j.geoforum.2005.12.001

Kirby, A. J. (1988), "Trade Associations as Information Exchange Mechanisms", The RAND Journal of Economics, Vol. 19., No 1, pp. 138. https://doi. org/10.2307/2555403

Lamberg, J.-A. - Laurila, J., - Nokelainen, T. (2017), "Institutional Path Dependence in Competitive Dynamics: The Case of Paper Industries in Finland and the USA" Managerial and Decision Economics, Vol. 38., No 7, pp. 971-991. https://doi.org/10.1002/mde.2839 
Lane, C., - Bachmann, R. (1997), "Co-operation in Inter-Firm Relations in Britain and Germany: The Role of Social Institutions", The British Journal of Sociology, Vol. 48. No 2, pp. 226-254. https://doi.org/10.2307/591750

Larrain, M. - Prüfer, J. (2015), "Trade Associations, Lobbying, and Endogenous Institutions", Journal of Legal Analysis, Vol. 7., No 2, pp. 467-516. https://doi. org/10.1093/jla/lav009

Lenox, M. J. - Nash, J. (2003), "Industry self-regulation and adverse selection: A comparison across four trade association programs" Business Strategy and the Environment, Vol. 12., No 6, pp. 343-356. https://doi.org/10.1002/bse.380

Leonidou, L. C. - Katsikeas, C. S. (1997), "Export information sources: The role of organizational and internationalization influences" Journal of Strategic Marketing, Vol. 5., No 2, pp. 65-87. https://doi.org/10.1080/096525497346802 Levine, M. E. - Forrence, J. L. (1990), "Regulatory Capture, Public Interest, and the Public Agenda: Toward a Synthesis", Journal of Law, Economics, and Organization, Vol. 6., pp. 167.

Lindberg, L. N. - Campbell, J. L., - Hollingsworth, J. R. (1991), "Economic governance and the analysis of structural change in the American economy" In J. L. Campbell, J. R., Hollingsworth, L. N. Lindberg eds., Governance of the American economy (pp. 3-34). Cambridge University Press.

Luna, M. - Tirado, R. (2008), "Business associations and their contribution to knowledge networks in Mexico" International Journal of Technology Management and Sustainable Development, Vol. 7., No 3, pp. 251-264. https:// doi.org/10.1386/ijtm.7.3.251_1

Maennig, W. - Ölschläger, M. - Schmidt-Trenz, H.-J. (2015), "Organisations and regional innovative capability: The case of the chambers of commerce and industry in Germany", Environment and Planning C: Government and Policy, Vol. 33., No 4, pp. 811-827. https://doi.org/10.1068/c12201b

Marques, J. C. (2017), "Industry Business Associations: Self-Interested or Socially Conscious?" Journal of Business Ethics, Vol. 143., No 4, pp. 733-751. https://doi.org/10.1007/s10551-016-3077-y

Masten, S. E. - Prüfer, J. (2014), "On the Evolution of Collective Enforcement Institutions: Communities and Courts", The Journal of Legal Studies, Vol. 43., No 2, pp. 359-400. https://doi.org/10.1086/677837

Mattli, W. - Büthe, T. (2005), "Accountability in Accounting? The Politics of Private Rule-Making in the Public Interest", Governance, Vol. 18., No 3, pp. 399-429. https://doi.org/10.1111/j.1468-0491.2005.00282.x

McCormick, L. E. - Hawley, J. D., - Meléndez, E. (2008), "The Economic and Workforce Development Activities of American Business Associations", Economic Development Quarterly, Vol. 22., No 3, pp. 213-227. https://doi. org/10.1177/0891242408321694 
McMillan, J. - Woodruff, C. (2000), "Private Order under Dysfunctional Public Order", Michigan Law Review, Vol. 98., No 8, pp. 2421-2458. JSTOR. https:// doi.org/10.2307/1290349

McNamara, D.L.(1993), "Association and Adjustment in Japan's Textile Industry", Pacific Affairs, Vol. 66., No 2, pp. 206. https://doi.org/10.2307/2759367

Mikamo, S. (2013), "Business associations and politics in the post-EDSA Philippines: Neither oligarchy nor civil society", Philippine Political Science Journal, Vol. 34., No 1, pp. 6-26. https://doi.org/10.1080/01154451.2013.789165

Mike, K. (2017), "The intellectual orders of a market economy" Journal of Institutional Economics, Vol. 13., No 4, pp. 899-915. https://doi.org/10.1017/ S1744137417000029

Moore, M., - Hamalai, L. (1993), "Economic liberalization, political pluralism and business associations in developing countries", World Development, Vol. 21., No 12, pp. 1895-1912. https://doi.org/10.1016/0305-750X(93)90065-H

Muraközy, B., - Valentiny, P. (2015), "Alternatives to state regulation: Self- and co-regulation" In P. Valentiny, F. L. Kiss, K. Antal-Pomázi, C. I. Nagy eds., Competition and regulation, 2015 (pp. 54-95). Institute of Economics, Centre for Economic and Regional Studies, Hungarian Academy of Sciences.

Nordqvist, M. - Picard, R. G., - Pesämaa, O. (2010), "Industry Associations as Change Agents: The Institutional Roles of Newspaper Associations", Journal of Media Business Studies, Vol. 7., No 3, pp. 51-69. https://doi.org/10.1080/16 522354.2010.11073511

Nugent, J. B., - Sukiassyan, G. (2009), "Alternative Strategies for Firms in Oppressive and Corrupt States: Informality or Formality Via Business Associations?" Contemporary Economic Policy, Vol. 27., No 4, pp. 423-439. https://doi.org/10.1111/j.1465-7287.2009.00171.x

Olson, M. (1971), The Logic of Collective Action. Harvard University Press.

Ostrom, E. (2005), Understanding institutional diversity. Princeton University Press.

Perez-Aleman, P. (2003), "A Learning-Centered View of Business Associations: Building Business-Government Relations for Development", Business and Politics, Vol. 5., No 2, pp. 193-213. https://doi.org/10.2202/1469-3569.1054 Polanyi, M. (1951), The logic of liberty: Reflections and rejoinders. Liberty Fund.

Prüfer, J. (2016), "Business Associations and Private Ordering", The Journal of Law, Economics, and Organization, Vol. 32., No 2, pp. 306-358. https://doi. org/10.1093/jleo/ewv017

Pyle, W. (2005), "Contractual Disputes and the Channels for Inter-firm Communication", Journal of Law, Economics and Organization, Vol. 21., No 2, pp. 547-575. https://doi.org/10.1093/jleo/ewi014 
Pyle, W. (2006a), "Collective action and post-communist enterprise: The economic logic of Russia's business associations", Europe-Asia Studies, Vol. 58., No 4, pp. 491-521. https://doi.org/10.1080/09668130600652068

Pyle, W. (2006b), "Resolutions, recoveries and relationships: The evolution of payment disputes in Central and Eastern Europe", Journal of Comparative Economics, Vol.34., No 2,pp.317-337.https://doi.org/10.1016/j.jce.2006.02.002 Pyle, W. (2011), "Organized Business, Political Competition, and Property Rights: Evidence from the Russian Federation", The Journal of Law, Economics, and Organization, Vol. 27., No 1, pp. 2-31. https://doi.org/10.1093/ jleo/ewp013

Qiao, P. - Ju, X., - Fung, H.-G. (2014), "Industry association networks, innovations, and firm performance in Chinese small and medium-sized enterprises", China Economic Review, Vol. 29., pp. 213-228. https://doi. org/10.1016/j.chieco.2014.04.011

Rademakers, M. (2000), "Agents of trust: Business associations in agri-food supply systems", The International Food and Agribusiness Management Review, Vol. 3., No 2, pp. 139-153. https://doi.org/10.1016/S10967508(00)00029-X

Recanatini, F., - Ryterman, R. (2001), Associations in a Transition Economy (No. 2359; POLICY RESEARCH WORKING PAPER, p. 42).

Rees, J. (1997), "Development of Communitarian Regulation in the Chemical Industry", Law \& Policy, Vol. 19., No 4, pp. 477-528. https://doi. org/10.1111/1467-9930.00036

Reveley, J. - Ville, S. (2010), "Enhancing Industry Association Theory: A Comparative Business History Contribution", Journal of Management Studies, Vol. 47., No 5, pp. 837-858. https://doi.org/10.1111/j.14676486.2010.00926.x

Rochlitz, M. (2016), "Collective Action Abroad: How Foreign Investors Organize Evidence from Foreign Business Associations in the Russian Federation", SSRN Electronic Journal. https://doi.org/10.2139/ssrn.2722486

Saitgalina, M. - Zhao, T. - Stebbins, R. A. - Smith, D. H. (2016), "Participation in Trade and Business Associations", In D. H. Smith, R. A. Stebbins, J. Grotz eds., The Palgrave Handbook of Volunteering, Civic Participation, and Nonprofit Associations (pp. 417-435). Palgrave Macmillan UK. https://doi. org/10.1007/978-1-137-26317-9_20

Schmitter, P. C. - Streeck, W. (1999), The Organization of Business Interests: Studying the associative action of business in advanced industrial societies [Working Paper]. http://cadmus.eui.eu//handle/1814/21980

Schneiberg, M. (1999), "Political and Institutional Conditions for Governance by Association: Private Order and Price Controls in American Fire 
Insurance" Politics \& Society, Vol. 27., No 1, pp. 67-103. https://doi. org/10.1177/0032329299027001004

Schneider, B. R. (2010), "Crises and Institutional Origins: Business Associations in Latin America", In R. F. Doner ed., Explaining Institutional Innovation (pp. 57-67). Social Science Research Council.

Schneider, B. R. - Doner, R. F. (2000), "The new institutional economics, business associations, and development", Brazilian Journal of Political Economy, Vol. 20., No 3, pp. 39-62.

Schwartz, D. - Bar-El, R. (2015), "The Role of a Local Industry Association as a Catalyst for Building an Innovation Ecosystem: An Experiment in the State of Ceara in Brazil", Innovation, Vol. 17., No 3, pp. 383-399. https://doi.org/10. 1080/14479338.2015.1075855

Stolz, T. - Schrammel, T. (2014), Business Membership Organizations as a policy approach to increase SMEs' EU funds absorption.

Sukiassyan, G. - Nugent, J. B. (2011), "Lobbying or Information Provision: Which Functions of Associations Matter Most for Member Performance?" Eastern European Economics, Vol. 49., No 2, pp. 30-63. https://doi. org/10.2753/EEE0012-8775490202

Tollison, R. D. (1982), "Rent Seeking: A Survey", Kyklos, Vol. 35., No 4, pp. 575-602. https://doi.org/10.1111/j.1467-6435.1982.tb00174.x

Tollison, R. D. (2012), "The economic theory of rent seeking", Public Choice, Vol. 152., No 1, pp. 73-82. https://doi.org/10.1007/s11127-011-9852-5

Tucker, A. (2008), "Trade Associations as Industry Reputation Agents: A Model of Reputational Trust", Business and Politics, Vol. 10., No 1, pp. 1-26. https:// doi.org/10.2202/1469-3569.1218

Ville, S. (2007), "Rent Seeking or Market Strengthening? Industry Associations in New Zealand Wool Broking", The Business History Review, Vol. 81., No 2, pp. 297-321. https://doi.org/10.1017/s0007680500003378

Yakovlev, A. -Sobolev, A. - Kazun, A. (2014), "Means of production versus means of coercion: Can Russian business limit the violence of a predatory state?" Post-Soviet Affairs, Vol. 30., No 2-3, pp. 171-194. https://doi.org/10.10 80/1060586X.2013.859434

Yue, L. Q. - Luo, J. - Ingram, P. (2013), "The Failure of Private Regulation: Elite Control and Market Crises in the Manhattan Banking Industry", Administrative Science Quarterly, Vol. 58., No 1, pp. 37-68. https://doi. org $/ 10.1177 / 0001839213476502$ 
